Education

\title{
Pengaruh Sikap Terhadap Pelajar di UPSI Apabila Menggunakan Aplikasi Permainan Atas Talian
}

\author{
Siti Nurhamiyah Mail ${ }^{1}$, Laili Farhana Md Ibharim ${ }^{1}$ \\ ${ }^{1}$ Fakulti Seni, Komputeran dan Industri Kreatif, Universiti Pendidikan Sultan Idris. \\ Tanjong Malim, Malaysia.
}

Article History
Received:
05.09 .2020
Revised:
21.11 .2020
Accepted:
06.12 .2020
*Corresponding Author:
Laili Farhana Md Ibharim
Email:
laili@fskik.upsi.edu.my

This is an open access article, licensed under: $\mathrm{CC}-\mathrm{BY}-\mathrm{SA}$
Abstrak: Permainan atas talian semakin menjadi pilihan pelajar untuk mengisi masa terluang seiring dengan perkembangan dalam teknologi maklumat. Penggunaan aplikasi permainan atas talian menggunakan telefon pintar banyak mempengaruhi dan membentuk budaya hiburan pelajar pada masa kini. Kajian ini bertujuan untuk membincangkan pengaruh sikap terhadap pelajar UPSI apabila bermain aplikasi permainan atas talian. Kajian tinjauan ini melibatkan seramai 60 orang pelajar Diploma kursus Pembangunan Permainan 2D UPSI dan data dikumpulkan dengan menggunakan aplikasi MYGURU UPSI melalui perbincangan forum "Faktor dan Kesan Permainan Digital". Penyelidik menggunakan kaedah analisis dokumen untuk mengumpul data tersebut. Dapatan kajian mendapati rakanrakan merupakan faktor utama yang mempengaruhi pelajar untuk bermain permainan atas talian. Kesan positif yang utama apabila bermain permainan atas talian ialah dapat meningkatkan kemahiran berfikir, pengetahuan dan pemikiran logik manakala kesan negatif yang utama pula ialah masalah kesihatan seperti rabun, obesiti, dan masalah tidur yang tidak teratur. Kajian ini boleh dijadikan rujukan kepada para pelajar untuk memanfaatkan permainan yang bersesuaian dan membantu mereka dalam memperolehi impak positif dalam hidupan seharian serta membantu pensyarah dalam mengubahsuai strategi pengajaran dan pembelajaran untuk menarik minat pelajar.

Kata Kunci: Pengaruh Sikap, Permainan Atas Talian, Teknologi Instruksional.

\section{Attitudes Influence on UPSI Students in Using Online Game Applications}

Abstract: Online games are increasingly becoming the choice of students to fill their free time in line with developments in information technology. The use of online gaming applications using smartphones greatly influences and shapes the entertainment culture of students nowadays. This study aims to discuss the influence of attitudes on UPSI students when playing online game applications. This survey study involved a total of 60 Diploma students of UPSI 2D Game Development course and data were collected using the MYGURU UPSI application through the discussion of the "Faktor dan Kesan Permainan Digital" forum. Researchers use document analysis methods to collect such data. The findings of the study found that peers are a major factor influencing students to play online games. The main positive effects when playing online games is to improve thinking skills, knowledge and logical thinking while the main negative effects are health problems such as myopia, obesity, and irregular sleep problems. This study can be used as a reference for students to take advantage of appropriate games and assist them in obtaining a positive impact in daily life as well as assist lecturers in modifying teaching and learning strategies to attract students.

Keywords: Attitude Influence, Instructional Technology, Online Games. 


\section{Pendahuluan}

Ledakan teknologi moden pada masa kini membawa impak yang besar terhadap kehidupan dan sikap seseorang pelajar itu. Aktiviti pelajar pada abad ke 21 masa kini lebih terdedah kepada penggunaan peralatan gadjet berteknologi seperti internet, komputer, dan telefon pintar. Menurut Nahar \& Sangi [1], secara purata dalam sehari, pelajar menghabiskan masa selama lapan jam dalam menggunakan peralatan teknologi seperti telefon pintar. Hal ini menyebabkan perkembangan hidup dan sikap pelajar dipengaruhi oleh teknologi tersebut.

Tinjauan daripada Jabatan Perangkaan Malaysia dan Suruhanjaya Komunikasi dan Multimedia Malaysia menunjukkan bahawa permainan atas talian menjadi salah satu pilihan remaja untuk mengisi masa mereka. Menurut tinjauan daripada Jabatan Perangkaan Malaysia [2], sebanyak 97.7 peratus individu menggunakan telefon pintar pada tahun 2017. Aktiviti yang pelajar gunakan semasa menggunakan telefon pintar pula adalah bermain atau memuat turun permainan yang menduduki tempat kedua dalam aktiviti utama penggunaan internet di Malaysia. Hal ini menunjukkan bahawa pelajar memperuntukan masa yang banyak untuk bermain permainan atas talian dengan menggunakan telefon pintar.

Seiring dengan peningkatan aktiviti pelajar dalam bermain permainan atas talian, kesan penggunaan permainan atas talian sering menjadi perdebatan dalam kalangan penyelidik. Banyak kajian lepas yang menunjukkan bahawa permainan atas talian lebih banyak membawa kesan negatif kepada pelajar. Namun, terdapat juga aplikasi permainan atas talian yang membantu meningkatkan kesan positif terhadap sikap pelajar.

\section{Permainan Atas Talian}

Istilah permainan atas talian (online game) berasal daripada istilah Massively Multiplayer Online Role-Playing Game (MMORPG) iaitu jenis permainan Role-Playing Game yang memiliki kemudahan pemain berganda, di mana seorang pemain dapat menghubungkan komputer, telefon pintar, dan pelbagai gadjet lain ke sebuah pelayan (server) dan melalui pelayan tersebut, pemain dapat bermain bersama ribuan pemain di seluruh dunia. Menurut Adams \& Rollings [3], permainan atas talian adalah permainan yang dapat diakses oleh ramai pemain dengan menggunakan mesin dan dihubungkan dengan jaringan internet.

Terdapat pelbagai genre permainan atas talian yang boleh didapati dengan mudah. Menurut Adams [4], permainan memiliki genre yang luas antaranya ialah,

1. Aksi dan Permainan Arked, permainan yang melibatkan kemampuan fizikal dan memerlukan kordinasi tangan dan mata yang baik.

2. Permainan Strategi, permainan yang memerlukan taktik dan logik serta kemahiran berfikir.

3. Permainan Berdasarkan Peranan, permainan yang membolehkan pemain berinteraksi ke dunia maya dan membolehkan pemain memainkan pelbagai jenis karakter.

4. Permainan Sukan, permainan yang mensimulasikan sukan dan olahraga.

5. Simulator Kenderaan, permainan mensimulasikan mengawal kenderaan seperti kereta, motor atau kapal.

6. Permainan Pembinaan dan Simulasi, permainan yang memerlukan pemain membangun, mengatur dan mengendalikan sesuatu.

7. Permainan Pengembaraan, permainan yang memiliki jalan cerita interaktif mengenai karakter yang dimainkan.

8. Permainan Teka Teki, permainan yang secara asasnya menyelesaikan teka teki dan memerlukan pemikiran logik atau pemahaman sesuatu proses.

\section{Pengaruh Sikap Pelajar Apabila Bermain Permainan Atas Talian Berdasarkan Theory of Reasoned Action}

Pengaruh sikap seseorang terhadap kelakuan merujuk kepada penilaian individu tersebut bahawa sekiranya pelaksanaan sesuatu kelakuan itu adalah baik atau buruk. Berdasarkan Theory of Reasoned Action (TRA), sikap merupakan satu fungsi daripada kepercayaan. TRA. Fishbein \& Ajzen [5] telah mengkaji hubungan di antara kepercayaan, sikap dan perlakuan dan seterusnya telah membangunkan satu model struktur sikap.

Model TRA ini mencadangkan bahawa kepercayaan individu mempengaruhi sikap individu dan seterusnya membentuk niat yang akan menghasilkan perlakuan. Menurut Ramdhani [6], dalam TRA ini, niat seseorang untuk melakukan sesuatu menentukan sama ada dia akan melakukan atau tidak 
melakukan sesuatu itu. Secara skematik, TRA digambarkan seperti skema di Rajah 1.

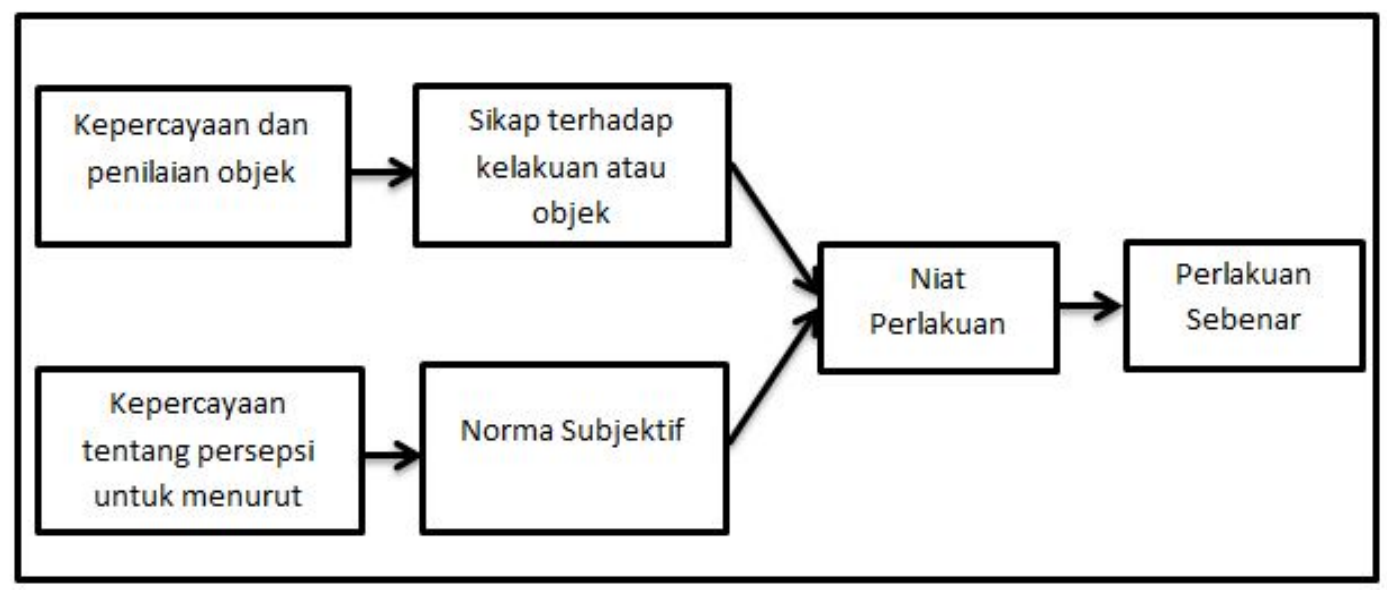

Rajah 1. Theory of Reasoned Action oleh Fishbein \& Ajzen [5]

Pada umumnya, seseorang individu yang mempercayai bahawa pelaksanaan sesuatu kelakuan akan membawa hasil positif dan ini akan menyebabkan individu tersebut menunjukkan satu sikap yang baik kearah pelaksanaan kelakuan tersebut dan sebaliknya. Sebagai contoh, pelajar yang mempercayai bahawa bermain pemainan atas talian akan memberi kebaikan dalam kehidupan sehariannya, maka pelajar tersebut akan membentuk satu sikap yang positif dan seterusnya mempengaruhi pelajar untuk bermain permainan atas talian tersebut. Terdapat pelbagai pengaruh sikap yang boleh didapati terhadap pelajar apabila bermain permainan atas talian. Pengaruh sikap tersebut boleh dikategorikan kepada pengaruh sikap positif dan negatif.

\section{Pengaruh Sikap Terhadap Pelajar di UPSI Apabila Menggunakan Aplikasi Permainan Atas} Talian

Berdasarkan kajian tinjauan, forum yang menggunakan platform Learning Management System MyGuru yang dilakukan oleh penyelidik terhadap 60 orang pelajar yang mengambil subjek Pembangunan Permainan 2D di Universiti Pendidikan Sultan Idris terdapat beberapa faktor yang mempengaruhi pelajar bermain permainan atas talian. Tempoh perbincangan forum yang dilakukan selama dua jam dan pelajar perlu membincangkan topik forum iaitu "Faktor dan Kesan Permainan Digital". Hasil perbincangan tersebut penyelidik telah melakukan analisis terhadap kandungan perbincangan forum dengan mengelaskan faktor utama yang mempengaruhi mereka bermain permainan atas talian dan mengkategorikan kesan sikap positif dan negatif akibat bermain permainan atas talian.

Responden menunjukkan bahawa rakan merupakan faktor utama yang mempengaruhi mereka bermain permainan atas talian diikuti. Hal ini demikian kerana mereka sering menghabiskan masa bersama rakan tidak kira semasa di waktu kuliah atau di luar waktu kuliah. Faktor seterusnya ialah permainan atas talian itu sendiri yang menawarkan cabaran, genre, jalan cerita dan grafik yang menarik. Selain itu, faktor diri sendiri yang berminat untuk mencuba dan mengisi masa lapang. Diikuti faktor mengikuti perkembangan trend semasa dan akhir sekali disebabkan oleh faktor ibu bapa yang tidak mempunyai masa untuk diluangkan bersama anak mereka.

Responden juga menunjukkan bahawa kesan positif yang utama apabila bermain permainan atas talian ialah dapat meningkatkan kemahiran berfikir, pengetahuan dan pemikiran logik apabila memilih genre permainan yang bersesuaian, dapat mengurangkan tekanan yang dialami dengan melepaskan kemarahan semasa bermain, dapat menambah semangat berkerjasama apabila bermain secara berkumpulan, dapat menambah kenalan di dunia maya, dapat meningkatkan fokus semasa melakukan sesuatu, dapat meningkatkan tahap imaginasi dan daya kreativiti, dan akhir sekali dapat mengisi masa lapang para pelajar.

Kesan negatif yang utama akibat bermain permainan atas talian pula ialah pelajar akan mengalami masalah kesihatan seperti rabun, obesiti, dan masalah tidur yang tidak teratur, dapat menimbulkan 
sikap agresif dalam diri seperti membentak dan menjerit sekiranya mengalami kekalahan, menjadikan pelajar antisosial di dunia sebenar kerana tidak bergaul dengan ahli keluarga atau rakan sekuliah, membazir masa akibat sering melayari internet untuk bermain permainan atas talian, mengakibatkan ketagihan bermain permainan, menimbulkan tabiat menangguhkan kerja, membazir duit untuk membeli perkara yang berkaitan permainan atas talian dan akhir sekali menyebabkan prestasi akademik merosot.

Jadual 1 seperti di bawah menunjukkan kesan positif dan kesan negatif akibat bermain permainan atas talian menurut hasil analisis perbincangan forum pelajar yang dijalankan oleh penyelidik. Senarai kesan tersebut merupakan hasil daripada kesan yang paling utama sehingga kesan yang paling sedikit dialami oleh pelajar akibat bermain permainan atas talian.

Jadual 1. Jadual Kesan Positif dan Kesan Negatif Terhadap Sikap Pelajar UPS Apabila Menggunakan Aplikasi Permainan Atas Talian

\begin{tabular}{cll}
\hline Perkara/Bil & \multicolumn{1}{c}{ Kesan Positif } & \multicolumn{1}{c}{ Kesan Negatif } \\
\hline 1. & $\begin{array}{l}\text { Meningkatkan kemahiran } \\
\text { berfikir, pengetahuan dan } \\
\text { pemikiran logik. }\end{array}$ & $\begin{array}{l}\text { Mengalami masalah } \\
\text { kesihatan. }\end{array}$ \\
\hline 2. & $\begin{array}{l}\text { Mengurangkan tekanan yang } \\
\text { dialami dengan melepaskan } \\
\text { kemarahan semasa bermain. }\end{array}$ & Menimbulkan sikap agresif. \\
\hline 3. & $\begin{array}{l}\text { Dapat menambah semangat } \\
\text { berkerjasama apabila bermain } \\
\text { secara berkumpulan. }\end{array}$ & $\begin{array}{l}\text { Menjadikan pelajar antisosial } \\
\text { di dunia sebenar. }\end{array}$ \\
\hline 4. & $\begin{array}{l}\text { Dapat menambah kenalan di } \\
\text { dunia maya. }\end{array}$ & Membazir masa. \\
\hline 5. & $\begin{array}{l}\text { Meningkatkan fokus semasa } \\
\text { melakukan sesuatu }\end{array}$ & $\begin{array}{l}\text { Mengakibatkan ketagihan } \\
\text { bermain. }\end{array}$ \\
\hline 6. & $\begin{array}{l}\text { Meningkatkan tahap } \\
\text { imaginasi dan daya kreativiti. }\end{array}$ & $\begin{array}{l}\text { Menimbulkan tabiat } \\
\text { menangguhkan kerja. }\end{array}$ \\
\hline 7. & Mengisi masa lapang. & Membazir duit. \\
\hline 8. & & $\begin{array}{l}\text { Menyebabkan prestasi } \\
\text { akademik merosot. }\end{array}$ \\
\hline
\end{tabular}

\subsection{Pengaruh Sikap Positif Apabila Bermain Permainan Atas Talian}

Pengelibatan pelajar dalam permainan atas talian banyak membawa kepada pengaruh sikap positif ke atas diri pelajar. Kajian daripada Bavelier \& Shawan [7] menunjukkan kemahiran dan tumpuan pelajar meningkat dengan bermain permainan peperangan dan tembak menembak. Hal ini demikian kerana, menerusi permainan ini, pelajar perlu lebih fokus semasa bermain untuk mengelakkan mereka kalah pada awal permainan. Genre aplikasi permainan yang memerlukan daya fokus yang tinggi seterusnya membantu pelajar untuk lebih fokus semasa sesi pengajaran dan pembelajaran.

Kajian Merry \& Stasial [8] menyatakan, "SPARX" sebuah permainan yang membantu pemain pulih daripada tekanan. Hasil kajian tersebut sangat menggalakkan di mana kira-kira 44 peratus daripada pemain pulih sepenuhnya daripada tekanan. Hal ini menunjukkan, dengan pemilihan genre permainan yang bersesuaian, pelajar berpotensi mengurangkan tekanan yang mereka hadapi. Pelajar boleh mencari permainan yang membantu mengurangkan tekanan yang mereka hadapi dan seterusnya membantu membentuk sikap positif dalam diri pelajar.

Pemilihan corak permainan yang bersesuaian sangat penting kepada pelajar. Hal ini membolehkan pelajar mendapatkan manfaat yang positif seterusnya membantu dalam kehidupan seharian mereka. Sebagai contoh, pelajar yang memilih genre permainan yang mencabar minda seperti permainan teka teki 'Quick Brain Mathematics', membantu mengembangkan kemahiran pelajar tersebut dalam subjek matematik. Hal ini disokong melalui kajian daripada Overmars (2005) dalam Zakirah \& Fadhilah [9] yang menyatakan bahawa bermain permainan atas talian boleh meningkatkan pemikiran logik dan pengiraan. Jika pelajar ingin menguasai kemahiran Bahasa, pelajar boleh mencari aplikasi permainan 
yang menawarkan pembelajaran Bahasa dan lain-lain.

Namun begitu, terdapat juga pengaruh sikap negatif dalam permainan atas talian terutamanya yang berorientasikan hiburan dengan lagak ngeri, ganas dan pembunuhan.

\subsection{Pengaruh Sikap Negatif Apabila Bermain Permainan Atas Talian}

Kajian oleh Rika [10] menunjukkan bahawa permainan atas talian mempengaruhi perubahan perilaku agresif remaja. Pelajar yang meluangkan masa secara berlebihan bermain permainan atas talian cenderung menimbulkan kesan negatif seperti bersikap kasar, agresif dan pemarah. Kristiyono [11] juga menyatakan bahawa bermain melebihi batasan menyebabkan sikap kasar dan agresif. Menurut Ananda [12] pula, kekerasan dalam permainan atas talian yang mempunyai impak kuat memungkinkan pelajar menjadi pemarah, memberontak, berkata kasar sehingga memukul.

Shuib [13] menjelaskan bahawa tumpuan pelajar menjadi terganggu kerana terlalu leka bermain telefon pintar sehingga tidak menghiraukan waktu pembelajaran. Hal ini menunjukkan pelajar yang banyak membuang masa bermain cenderung lupa, menangguh untuk melakukan aktiviti yang lebih penting di dunia sebenar sehingga tahap tidak menghiraukan tugasan yang perlu dilaksanakan.

Selain itu, kajian daripada Marjory \& Bonnie [14] menunjukkan bahawa pengunaan gadjet teknologi mendatakngkan kemudaratan kepada golongan pelajar seperti masalah perkembangan fizikal serta kesihatan disebabkan posisi badan yang tidak betul ketika menggunakan gadjet seperti telefon pintar tanpa kawalan.

\section{Kesimpulan}

Kesimpulannya, bermain aplikasi permainan atas talian mempunyai kesan positif dan negatif terhadap sikap pelajar, walau bagaimanapun genre dan corak permainan bermain oleh pelajar itu sebenarnya yang akan menentukan kesan terhadap pelajar tersebut. Kesan negatif yang berlaku ini akibat penggunaan aplikasi permainan atas talian secara keterlaluan, tidak terkawal dan genre permainan yang dipilih tidak bersesuaian dengan pelajar. Pelajar banyak menghabiskan masa bermain permainan atas talian, oleh itu inovasi seperti menggunakan aplikasi permainan atas talian untuk menarik minat pelajar bermain sambil belajar wajar dilaksanakan dan diperkasakan seiring dengan kemajuan teknologi masa kini. Justeru itu, kajian yang terperinci perlu dilakukan untuk mengenal pasti elemen yang bersesuaian yang boleh diterapkan dalam aplikasi permainan atas talian untuk membantu dan meningkatkan proses pengajaran dan pembelajaran pelajar, pensyarah serta mendatangkan impak positif terhadap sikap pelajar.

\section{Rujukan}

[1] N. Nahar, and S. Sangi, "Impak Negatif Teknologi Moden Dalam Kehidupan dan Perkembangan Kanak-Kanak Hingga Usia Remaja," International Journal of Islamic and Civilization Studies, pp. 87- 89, 2017.

[2] Jabatan Perangkaan Malaysia, Laporan Penyiasatan Penggunaan dan Capaian ICT oleh Individu dan Isi Rumah, Malaysia, 2017. [Online]. Available: https://www.dosm.gov. my/v1/index.php? $r=$ column/cthemeByCat\&cat=395\&bul_id=bHBzbWxkWElxRDlmaU81Q3R 2ckRkZz09\&menu_id=amVoWU54UT10a21NWmdhMjFMMWcyZz09. [Accessed: May, 12. 2020].

[3] E. Adams, and A. Rollings, Fundamentals of Game Design. Barkeley, CA: New Riders, 2010.

[4] E. Adams, Fundamentals of Game Design ( $3 r d$ ed). United States of Amerika: Pearson Education, Inc, 2010.

[5] M. Fishbein, and I. Ajzen, Belief, Attitude, Intention and Behavior: An Introduction to Theory and Research Reading, MA: Addison-wesley, 1975.

[6] N. Ramdhani, Model Perilaku Penggunaan IT “NR2007”, 2015. [Online]. Available: https://www.researchgate.net/publication/242196830_Model_Perilaku_Penggunaan_IT_NR200 7. [Accessed: May, 26. 2020].

[7] Bavelier, Daphne and C. S Green, "The Brain-Boosting Power of Video Games," Scientific American, 2016. [Online]. Available: http:scientificamerican0716-26. [Accessed: May, 12. 2020].

[8] S. N. Merry, and K. Stasial, "The effectiveness of SPARX, a computerised self help intervention for adolescents seeking help for depression: randomised controlled non-inferiority 
trial,” BMJ, 2012. [Online] Available: http/10.1136/bmj.e2598. [Accessed: April, 2. 2020].

[9] O. Zakirah, and M. Y. Fadhilah, Tinjauan Permainan Berkomputer Sebagai Alat Pembelajaran, 2007. [Online]. Available: http://www.MY\%20USER/Documents/Tinjauan_ Permainan_ Berkomputer.pdf. [Accessed: May, 12. 2020].

[10] A. A. Rika, "Pengaruh game online terhadap perubahan perilaku agresif remaja di Samarinda," eJournal Ilmu Komunikasi, vol.4, no. 3, pp. 290-304, 2016.

[11] J. Kristiyono, "Budaya internet: Perkembangan teknologi informasi dan komunikasi dalam mendukung media di masyarakat," Scriptura, 2015.

[12] E. M. Ananda, Pengaruh intensitas bermain game online dan pengawasan orang tua terhadap perilaku agresif anak. Semarang: Universitas Diponegoro, 2015.

[13] S. Shuib, Murid boleh bawa telefon bimbit asas sahaja-media sosial, Berita Awani, 2015. [Online]. Available: http://www.astroawani.com/berita-malaysia/muid-boleh-bawa-telefonasas-sahaja-media-sosial-51838. [Accessed: May, 26. 2020].

[14] E. Marjory, and Y. H. Y. Bonnie, "Singaporean Parents' view of Their Young Children's Acess and Use of Thenological Devices," Early Chilhood Education Journal, 2015. 